\title{
Educação de surdos: relato de uma experiência inclusiva para o ensino de ciências e biologia
}

\author{
Luiz Renato Martins Rocha* \\ Alexandra Renata Moretti** \\ Priscila Caroza Frasson Costa*** \\ Fabiano Gonçalves Costa****
}

\section{Resumo}

O presente estudo objetiva apresentar a eficácia de recursos didáticos diferenciados aplicados nas aulas de Ciências e Biologia para o ensino de alunos surdos. Adotamos como metodologia a pesquisa de abordagem qualitativa, do tipo exploratória e estudo de campo, por meio da análise dos sujeitos surdos. A influência da disciplina de LIBRAS (Língua Brasileira de Sinais) inserida na matriz curricular do curso de Ciências Biológicas foi de extrema importância, pois despertou o interesse dos pesquisadores para o tema. Como questão norteadora indicamos: É possível o ensino dos conteúdos de citologia e histologia para alunos surdos inclusos na rede regular? Os dados foram coletados durante cinco aulas, ministradas com diversos recursos didáticos para alunos com surdez de uma escola pública, situada no município de Bandeirantes-PR. Foram aplicados, aos alunos surdos, questionários prévios e posteriores às aulas. Os resultados foram positivos, demonstrando as vantagens de se utilizar os recursos didáticos diferenciados aplicados aos conteúdos de biologia celular e histologia para o ensino de alunos surdos. Destacamos a confecção de modelos com massa de modelar pelos alunos surdos ao final da sequência das aulas, o que caracterizou a compreensão dos conceitos. Ressaltamos, também, a importância de um intérprete de Libras em sala de aula e os investimentos na capacitação de professores para atuar com estes alunos.

Palavras-chave: Surdos; Recursos Diferenciados; Inclusão.

\footnotetext{
* Tradutor/interprete de LIBRAS/Língua Portuguesa da Universidade Tecnológica Federal do Paraná. Cornélio Procópio, Paraná, Brasil.

** Graduada em Ciencias Biológicas pela Universidade Estadual do Norte do Paraná. Cornélio Procópio, Paraná, Brasil.

*** Professora doutora da Universidade Estadual do Norte do Paraná. Bandeirantes, Paraná, Brasil.

**** Professor doutor da Universidade Estadual do Norte do Paraná. Bandeirantes, Paraná, Brasil.
} 


\section{Deaf education: report of an inclusive experience for teaching science and biology}

\section{Abstract}

This paper aims to present the effectiveness of different teaching resources invested in science and biology classes for teaching deaf students. We used the qualitative research methodology, exploratory method and field study to analyzes of deaf students. The fact of the discipline LIBRAS (Brazilian Signal Language) to be inserted in the curriculum of the course of biological science sparked the interest of the authors to start to work about the theme. As guiding questions we indicated: Is it possible to teach the cell biology and histology for deaf students inserted in the school system? The data were collected in five classes taught using a several teaching resource for deaf students of one public school, located in Bandeirantes-PR, Brazil. It were applied, to the deaf students, previous and posterior questionnaires the classes. The results were positive, because demonstrated advantages of the utilization of differentiated teaching resource applied in the cell biology and histology contends for deaf students. It is necessary to detach that, in this work, the manufacture of models with clay, realized by the deaf students, at the end of the sequence of classes, what helps in the increase of the comprehension of the contends. We also emphazise the importance of the interpreter of LIBRAS in the classroom and the necessity of the training of the teachers for act with deaf students.

Keywords: Deaf; Differentiated resources; Inclusion.

\section{Introdução}

A educação especial inclusiva nas escolas regulares de rede pública vem sendo alvo de grandes desafios e discussóes para os profissionais desta área, que lutam pela construção do direito à educação para todos (LACERDA, 2013).

Os surdos, sejam eles alunos ou não, possuem suas peculiaridades e cultura própria, que precisam ser respeitadas no convívio social. Sendo assim, os surdos não são considerados como deficientes, mas sim, diferentes linguísticos e assim como qualquer outro cidadão, tem o direito a se integrar no meio social (SACKS apud MONTEIRO 2011).

A política nacional da inclusão escolar salienta que os sistemas de ensino regular devem atender e respeitar as necessidades educacionais do aluno incluso na classe regular. Isto é, as escolas devem disponibilizar vários serviços, apoio pedagógico, estratégias e ainda um atendimento educacional especializado (CAMPOS; DUARTE, 2011).

Além disso, é indispensável a presença de um intérprete de LIBRAS capacitado em sala de aula, quando houver um aluno surdo matriculado. Tal necessidade deve-se ao fato de que o profissional capacitado transmitirá ao surdo as informaçóes orais com fidelidade (DORZIAT; ARAÚJO, 2012). 
Dentre esses e outros fatores que competem à inclusão escolar, a motivação e a capacitação de professores para a utilização de recursos diferenciados são primordiais (LACERDA; SANTOS, 2013). Sendo assim, acredita-se que propostas de ensino que visam à ampliação sensorial e tátil dos alunos surdos, mediadas por recursos didáticos diferenciados, podem contribuir com a melhoria da aprendizagem. Tais contribuiçóes visam proporcionar contextualizaçóes partindo de conceitos teóricos abstratos, gerando um ensino satisfatório decorrente de ferramentas estimulantes à aprendizagem significativa ao aluno surdo (VYGOTSKI, 1997).

Sendo assim, Costa e Kelman (2004) ressaltam que os conteúdos a serem transmitidos aos alunos surdos precisam ter sentido, a ponto de compreenderem tais assuntos, despertando o interesse e curiosidade dos mesmos. Desta forma, segundo Linhares e Taschetto (2009), os currículos de Ciências e Biologia, inseridos na matriz curricular do ensino básico, auxiliam na promoção da alfabetização científica do aluno. As disciplinas de Ciências e Biologia oferecem conceitos importantes que serão úteis para sua formação enquanto cidadão.

Para este mesmo autor, a partir do que verificou em seus estudos acerca do conteúdo "células" no ensino básico, pôde perceber que os conceitos relacionados caracterizam-se por serem distantes e abstratos para os alunos, pois oferecem pequenas noçôes, lhes parecendo real apenas na imaginação. Acarreta-se assim, a carência de recursos disponíveis, com ausência de visualização, observação e identificação das estruturas celulares. Devido a isso, torna-se difícil a compreensão de diferentes tipos de células e todo o seu contexto, a importância dos organismos e suas funçóes, e ainda mais o que compóe os tecidos, órgãos e sistemas.

Assim sendo, se em uma classe regular com alunos ouvintes os conteúdos relacionados à célula e tecido podem ficar distantes da realidade, tal situaçáo pode ser agravada para alunos surdos inclusos, que possuem uma maneira singular de entender e se expressar com o mundo (SKLIAR, 1998).

A motivação para a realização deste trabalho foi proveniente da disciplina de LIBRAS, inserida na matriz curricular do terceiro ano do curso de licenciatura em Ciências Biológicas da UENP/CLM, a partir do ano de 2012. Desde então, houve uma nova perspectiva de trabalho docente voltada aos alunos surdos, com reflexo na preocupação com o ensino de Ciências e Biologia.

Neste trabalho, objetivamos avaliar alguns recursos didáticos diversificados que foram aplicados em uma amostra de alunos surdos, que promovessem a compreensão de conteúdos de citologia e histologia no ensino de Ciências e Biologia. Tal como escreveu Fernandes (2011), os recursos didáticos são ferramentas cruciais no processo ensino-aprendizagem, pois, segundo as estratégias metodológicas e organização de forma inovadora no ambiente em sala, podem facilitar a interaçáo e comunicação entre todos, amenizando as dificuldades e quebrando as barreiras sociais. 


\section{Relato de caso - narrativas de uma experiência com alunos surdos}

Alunos com surdez foram os protagonistas deste presente estudo, onde se dispuseram a contribuir com paciência e colaboração com os pesquisadores para a realização da pesquisa.

Durante o percurso desta investigação, houve momentos de reflexôes para o preparo das aulas ministradas, de modo que os alunos surdos compreendessem com clareza os conteúdos abordados, assim como aponta Duboc:

[...] que esse profissional tenha condiçôes de realizar reflexôes e questionamentos sobre a sua prática, enfatizando o trabalho coletivo em detrimento da competitividade e acima de tudo respeitando os diferentes estilos de aprendizagem dos alunos, refletindo, planejando e assumindo a responsabilidade de estar formando homens e mulheres. (DUBOC, 2005, p. 4).

Em acordo com o autor, depois de longas horas de reflexão, foi possível levantar questôes problematizadoras, tais como, a maneira de se comunicar, o sinal de LIBRAS aprendido para ensinar e o treinamento da datilologia (alfabeto manual) para os termos que não tinham sinais. Estes aspectos foram relevantes para que no momento das aulas, além de mediado o conhecimento, fosse garantido a confiança de cada um dos alunos participantes desta pesquisa.

Desde o início ocorreu um processo gradual de proximidade com os alunos surdos, com o intuito de familiarizar e socializar, a fim de que pudessem sentir-se à vontade durante a execução do trabalho. Durante a jornada desta investigação, foram requeridas dedicação, paciência e criatividade para estimular as potencialidades destes alunos. Ressaltamos o fato de que os recursos disponíveis nas escolas são precários e escassos e, a partir disso, houve estímulos de inovação com o uso de recursos, destacando-se, assim, a utilização nas aulas do projetor multimídia e os aparatos táteisvisuais como o microscópio, maquetes e mini modelos didáticos.

Sendo assim, Monteiro afirma que:

Diversos recursos podem ser utilizados nas aulas [...], tais como: o livro didático, datashow, jogos, multimídia, softwares, laboratório, confecção de modelos, quadro branco, entre outros. Exige-se do professor competência, dedicação, determinação e envolvimento, além de condiçóes para manusear recursos tecnológicos de maneira satisfatória, tudo isso associado a um amplo conhecimento da disciplina e conhecimentos pedagógicos bem estabelecidos que o permita saber identificar e selecionar a melhor metodologia, baseado no conhecimento das características dos seus alunos, uma vez que é a aprendizagem do aluno que interessa ao professor. (MONTEIRO, 2011, p. 45). 
Ao perceberem abordagens diferentes no ensino, valendo-se dos recursos didáticos, os alunos estavam dispostos a aprender os conteúdos de Ciências e Biologia, já que ficaram estimulados à participação ativa, além de provocar estímulos causados por percepçóes visuais e táteis.

Vale ponderar que, ao ensinar Ciências e Biologia, o professor deve ter em mente a suma importância destes conteúdos na vida dos alunos, assim como apontam os autores Bybee e DeBoer apud Sasseron e Carvalho:

O currículo de ciências deve ser relevante para a vida de todos os estudantes [...]. E os métodos de instrução devem demonstrar cuidados para a diversidade de habilidades e interesses dos estudantes. (BYBEE e DEBOER apud SASSERON e CARVALHO, 2011, p $65)$.

O trabalho com alunos surdos é desafiador, porém motivador, principalmente ao saber que estes alunos, muitas vezes, são excluídos do meio escolar, inclusive dentro da própria sala de aula. $\mathrm{O}$ aspecto pedagógico de inclusão escolar ainda é polêmico e precisa ser discutido nos diversos segmentos da sociedade. Temos posto que está longe do ideal a preparação dos profissionais da educação para trabalhar com alunos especiais (LACERDA; SANTOS, 2013).

O ensino de Ciências Biológicas, bem como outras disciplinas de base comum, é visto com certa preocupação para os alunos surdos, pois, por vezes, os conteúdos e seus conceitos são descontextualizados e ensinados de forma independente, conforme podemos notar no trecho escrito por Oliveira, que comenta existir uma:

[...] falta de reflexão no sentido geral da educaçáo especial. São valorizadas as pesquisas, bem como discussōes sobre a cultura surda com relaçẫo à aquisição da língua natural (Língua de Sinais), a oralização, os processos fonoaudiológicos, psicológicos, mas discute-se menos ou não se discute a educação do surdo como um todo. Isto é, com exceção do português, faltam pesquisas na busca por estratégias para ensino de Matemática, Inglês, Geografia, Redação, Química, Física, etc. Em geral, tais estudos são realizados de forma independente por educadores que recebem estudantes surdos em suas classes e compreendem a necessidade de buscar meios para lhes assegurar o acesso à informação e ao conhecimento de sua disciplina. (OLIVEIRA, 2005, p. 14).

\section{Metodologia}

Os participantes desta pesquisa foram três surdos estudantes da Educação Básica, sendo dois deles do ensino fundamental e um do ensino médio, ambos de uma escola estadual do município de Bandeirantes-PR, com idades entre 14 e 16 anos. Para se referir aos alunos, utilizaremos as nomenclaturas A, B e C.

Esta pesquisa foi realizada no contraturno das aulas, nos mesmos horários utilizados para acontecer as aulas de reforço, durante seis semanas não-consecutivas, 
entre os meses de maio, junho e agosto de 2013. Cada aula foi ministrada no período matutino, com duração de uma hora. Foi realizada em sala de aula ou na sala de reforço escolar existente naquela instituição de ensino, tendo sido a penúltima aula ministrada no laboratório de aulas práticas do Setor de Biologia do Centro de Ciências Biológicas da UENP-CLM.

Os dados foram obtidos por meio da aplicação de questionários anteriores e posteriores às cinco primeiras aulas ministradas, sendo aplicadas sempre no início e no término de cada aula. Os questionários continham duas ou três questōes (apêndice) explicadas em LIBRAS (Língua Brasileira de Sinais) e respondidas pelos alunos separadamente, sem que tivessem contato com as respostas dos outros, a fim de que os alunos pudessem entender melhor a proposta do questionário.

\section{Etapas metodológicas}

Em cada uma das seis aulas ministradas foram utilizados recursos didáticos diferenciados, sendo que em todas, para melhorar a comunicação entre os pesquisadores e os alunos surdos, foi utilizada a lousa como suporte para a escrita, quando não era possível comunicar-se por meio dos sinais. $\mathrm{O}$ conteúdo foi dividido nos encontros, seguindo a sequência descrita abaixo.

Na primeira aula, foi utilizado apenas quadro branco e pincéis de cor azul, possibilitando fazer esquemas de desenhos e escritas, através dos quais foram apresentados conteúdos de introdução à citologia. Os desenhos foram esquematizados com inserçấo de setas, com intuito de nomear cada uma das estruturas importantes representadas no desenho da aula. Foram elaborados exemplos (desenhos) de organismos vivos para demonstrar que todos os seres são constituídos de células.

A segunda aula foi ministrada com o auxílio de um projetor multimídia conectado a um microcomputador, utilizando o software Microsoft Powerpoint ${ }^{\bullet} 2010$, para projetar desenhos esquemáticos. Tais desenhos tinham o objetivo de diferenciar células procariontes de células eucariontes e identificar alguns representantes destes grupos.

$\mathrm{Na}$ terceira aula, foi utilizada uma maquete de célula animal, com área de aproximadamente $900 \mathrm{~cm}^{2}$, feita de E.V.A. e plástico. A ideia de utilizar este recurso foi uma tentativa de estimular a percepção tátil e visual dos alunos, comparando a diferença de tamanho entre uma célula real e a célula representada na maquete. Outro objetivo desta mesma aula foi compreender a organizaçáo e disposiçáo das organelas dentro do citoplasma da célula eucariótica.

$\mathrm{Na}$ quarta aula, houve a proposta de um vídeo didático, retirado do site youtube (http://www.youtube.com/watch?v=j31Zbn2HMaE), acessado em: 19 jun. 2013, intitulado "Eu e meu corpo", com legendas inseridas, de modo a tornar mais acessível o conteúdo de histologia, ressaltando todos os tipos celulares presentes no corpo humano. Neste vídeo também foram apresentados os ramos de pesquisas em que um cientista pode trabalhar, visando descobertas celulares com o auxílio de um microscópio. 
A quinta aula ocorreu no laboratório do Setor de Biologia do CCB/UENPCLM, com os alunos surdos, a fim de que pudessem conhecer o microscópio e trabalhar assuntos de histologia. Foram utilizadas lâminas e lamínulas, reagente azul de metileno, dois microscópios de luz e um terceiro microscópio óptico com câmera acoplada, que capturava a imagem e apresentava numa televisão, manipulado pelos pesquisadores. Para preparar as lâminas, os alunos foram instruídos a confeccioná-las, utilizando palito para a raspagem das porçóes internas de suas bochechas, coletando células epiteliais de revestimento que facilmente se descamam. Para a comparação na escala de tamanho, utilizamos um livro didático, relacionando os tamanhos dos desenhos esquemáticos do livro com a célula visualizada no microscópio.

$\mathrm{Na}$ sexta aula, houve a proposta de uma atividade adicional, com massa de modelar colorida. Foi solicitado que os alunos surdos montassem uma célula utilizando as massas de modelar, de livre elaboração, de acordo com o que tinham entendido nas aulas anteriores. Tal atividade serviria para identificar o aprendizado dos pesquisados, não sendo aplicado nenhum questionário.

\section{Resultados e discussão}

O ensino de Ciências e Biologia, especificamente para os conteúdos de citologia e histologia, foi promovido utilizando como ferramenta recursos diversificados, com o intuito de estimular o interesse dos alunos surdos e ampliar suas percepçóes táteis e espaço-visual diante dos conteúdos apresentados. Pois, "para o professor é importante conhecer a peculiaridade e o caminho pelo qual se deve conduzir a criança deficiente" (VYGOTSKI, p. 17, 1997).

Na primeira aula, apenas dois alunos compareceram e o conteúdo ministrado foi "introduçáo à citologia". A aula em questáo teve como avaliação apenas duas questôes, e, de acordo com as respostas dos alunos, percebemos que o recurso utilizado náo foi plenamente satisfatório.

$\mathrm{O}$ aluno A caracterizou-se pelo desempenho parcial frente à atividade, considerando que antes das aulas não houve nenhum acerto no questionário prévio, porém, acertou metade das questóes no questionário posterior.

$\mathrm{O}$ aluno $\mathrm{B}$ teve melhor desempenho nas respostas do questionário prévio em relação ao questionário posterior. Notamos que, antes das aulas, o aluno já apresentava um conhecimento prévio e confundiu os conteúdos, devido provavelmente a não assimilaçáo dos mesmos. Contribuiu para isto o fato de que só foi utilizada a lousa branca como recurso.

Diante desta situação, observamos que os resultados estáo em acordo com a autora Spenassato (2009), que apontou que os alunos surdos necessitam de estratégias inovadoras de ensino, pois, quando o professor utiliza apenas o quadro e seus acessórios (giz ou pincel), os alunos surdos não tem interesse em aprender, por se deparar com dificuldades na compreensão dos conceitos das disciplinas, esbarrando novamente em sua dificuldade com a Língua Portuguesa. 
A segunda aula teve como enfoque as células procariontes e células eucariontes. Utilizou-se um projetor multimídia com alguns desenhos esquemáticos, a fim de representar os grupos de células procariontes e células eucariontes, com a participação de três alunos surdos no experimento. Para avaliação destes, foram elaboradas três questôes para a coleta de dados. Os resultados estiveram a contento nesta aula, pois acreditamos que o auxílio deste equipamento ajudou no melhor entendimento dos surdos.

O aluno A não obteve nenhum acerto nas respostas dos questionários prévios e posteriores. Percebemos que, neste conteúdo, o aluno surdo não conseguiu compreender a matéria dada. No entanto, notamos uma compreensão vinda do aluno $\mathrm{B}$, posterior à aula ministrada. $\mathrm{E}$, por fim, o aluno $\mathrm{C}$, que alcançou a totalidade de acertos no questionário, o que indicou a facilitação do conteúdo e a utilização da ferramenta.

De acordo com Plácido apud Amaral et. al (2007), o projetor multimídia conectado a um computador pode melhorar e potencializar as aulas de um professor em sala. As imagens processadas, conforme a Fig. 1 despertaram nos alunos a curiosidade e o interesse que lhes permitiram, de forma concreta, a facilitação da compreensão dos conteúdos. É viável o uso de informática para ensinar em sala de aula, e, principalmente em se tratando de alunos com surdez, vem sendo uma alternativa de comunicação e aprendizagem, abrindo portas e estabilizando a integração social.

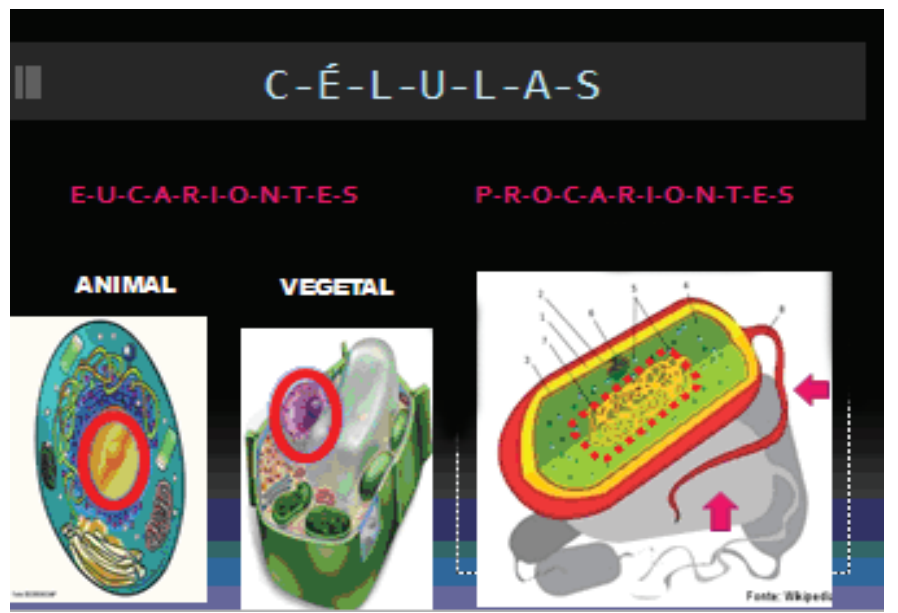

Figura 1 - Aula proposta com desenhos utilizados na aula com projetor multimídia.

Na terceira aula, foi proposta a utilização de uma maquete (Fig. 2) que representasse uma célula animal, demonstrando as organelas e a organização celular, onde participaram três alunos surdos. Foram elaboradas duas questóes objetivas para percepção da compreensão dos conceitos pelos alunos.

O aluno A não obteve resultado no questionário prévio, no entanto, ao participar das aulas, houve um resultado expressivo no questionário posterior. Já o aluno $\mathrm{B}$, obteve um resultado muito positivo no pós questionário, se comparado ao ques- 
tionário prévio. Percebemos ainda que, ao utilizar uma abordagem que almejasse os estímulos táteis e sensoriais, este aluno conseguiu assimilar e captar com sucesso os conteúdos discutidos na aula. No entanto, o aluno C não expressou relevância nos resultados, pois em nenhum dos questionários aplicados obteve acertos.

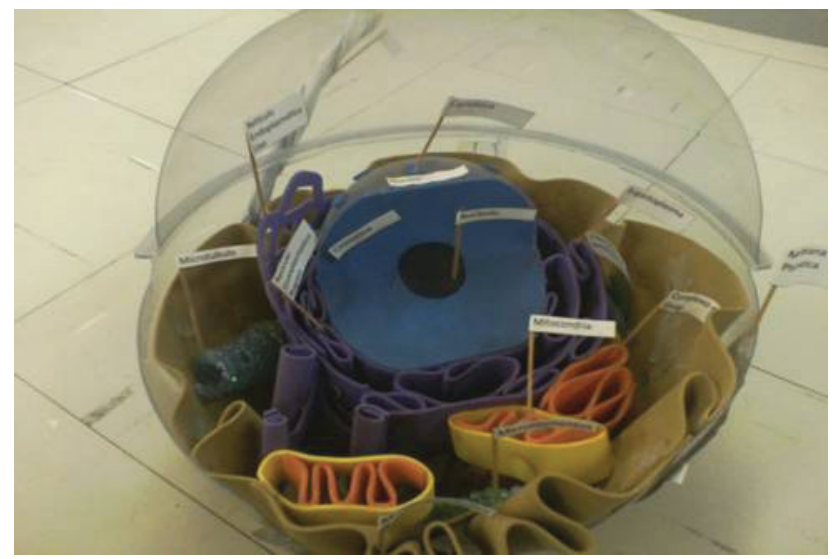

Figura 2: Aula proposta utilizando maquete de uma célula animal.

A estratégia de utilizar um recurso concreto e palpável é uma forma do professor contextualizar suas aulas, promovendo a aprendizagem do aluno. Com isso, ele poderá construir uma imagem em sua mente, possibilitando a fixação do conteúdo. Segundo Milan (2008), as maquetes táteis proporcionam captação de informaçôes, que auxiliam no aprendizado. Sendo assim, as imagens são construídas em seu processo cognitivo.

$\mathrm{Na}$ quarta aula, foi proposto um vídeo didático sobre os tecidos e células do corpo humano, na qual compareceram apenas dois alunos surdos. Para esta aula foi elaborada uma questão objetiva e uma questão aberta (envolvendo o desenho), a fim de que o aluno surdo pudesse expor no papel a sua imaginaçáo relacionada à célula.

Neste primeiro momento, considerando apenas a questão objetiva, o aluno A obteve resultado satisfatório apenas no questionário prévio. Enquanto que o aluno B teve respostas satisfatórias nos dois questionários, prévio e posterior.

Analisando os desenhos feitos pelos alunos que foram propostos somente no questionário posterior, visualizamos as figuras 3 e 4 : 


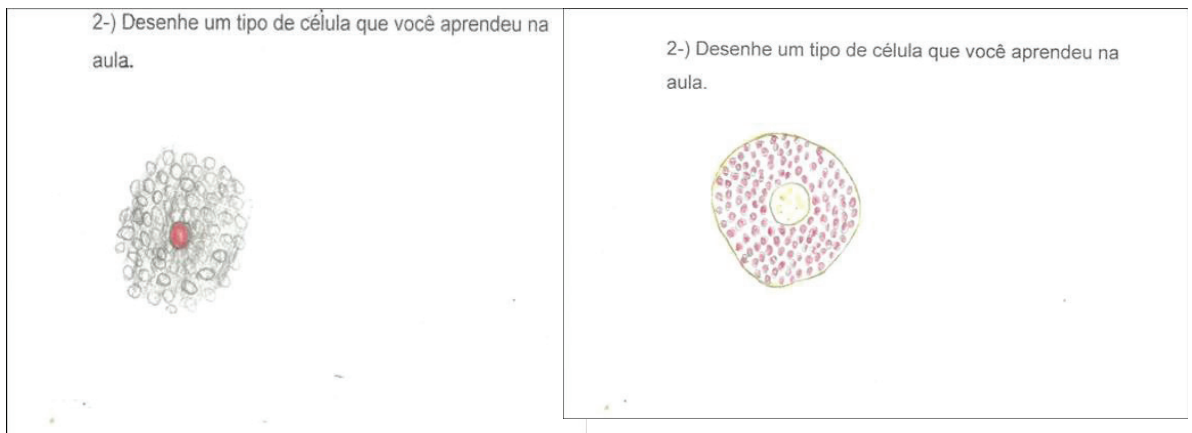

Figura 3: desenho feito pelo aluno A. Figura 4: desenho feito pelo aluno B.

Os desenhos realizados pelos alunos A e B condizem com o que entenderam frente ao vídeo proposto na aula. Vale ressaltar que o vídeo teve duração de aproximadamente sete minutos e quarenta segundos, com legendas inseridas em português, e mencionou alguns tipos de células e tecidos do corpo humano.

Neste contexto, Cisneiro-Filho e Leão (2009) afirmam que a eficiência da utilização de vídeos pode causar um impacto positivo na aprendizagem de alunos surdos, por ser uma estratégia extremamente visual. Deste modo, ao trabalhar aulas com vídeos didáticos para alunos surdos, acreditamos ser de suma importância que tenha a janela do intérprete de LIBRAS (Língua Brasileira de Sinais), pois, em consonância com Peixoto (2006), o surdo apresenta dificuldade em relação à produção e interpretaçáo com a língua portuguesa. Entretanto, nesses aspectos, sugerimos que o vídeo aplicado nesta aula não foi de excelente impacto, apesar de ter sido um importante recurso.

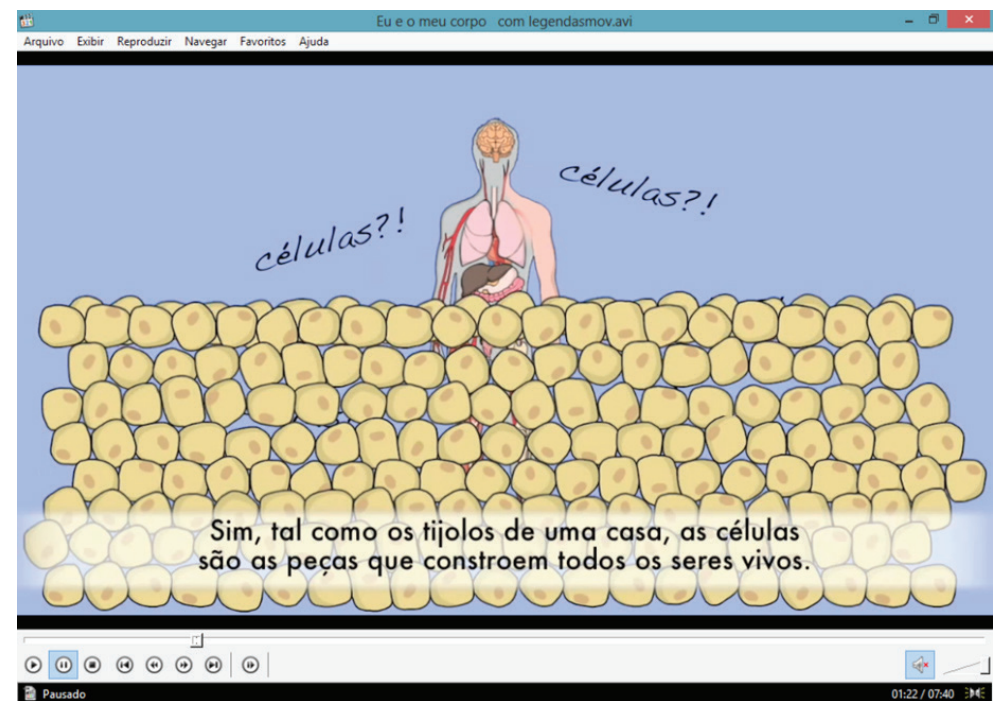

Figura 5: Parte do filme "Eu e meu corpo" legendado. 
A proposta da quinta aula foi a utilização do microscópio como recurso didático da aula sobre tecido celular. Nesta aula, dois alunos surdos se submeteram à visita no laboratório CCB/UENP - CLM. Como parte da mesma, houve a construção de suas próprias lâminas, a partir do esfregaço do tecido bucal. Foram elaboradas duas questôes objetivas nos questionários prévio e posterior, como coleta de dados. E, por último, uma questáo aberta para desenhar o que os alunos surdos haviam visto em suas respectivas lâminas.

Em relação às questôes objetivas (apêndices questionário aula 4), tanto o aluno A quanto o aluno $\mathrm{B}$ expressaram resultados positivos no pós questionário, se comparado ao questionário prévio, que foi aplicado no segundo momento após a aula ministrada.

Ao analisar os desenhos feitos pelos alunos (Fig. 6 e Fig. 7), é relevante apontar que, quando propomos um desenho da célula, possibilitamos a compreensão dos conceitos a partir de uma percepção unicamente visual, que resultou praticamente em uma cópia da célula vista no microscópio.

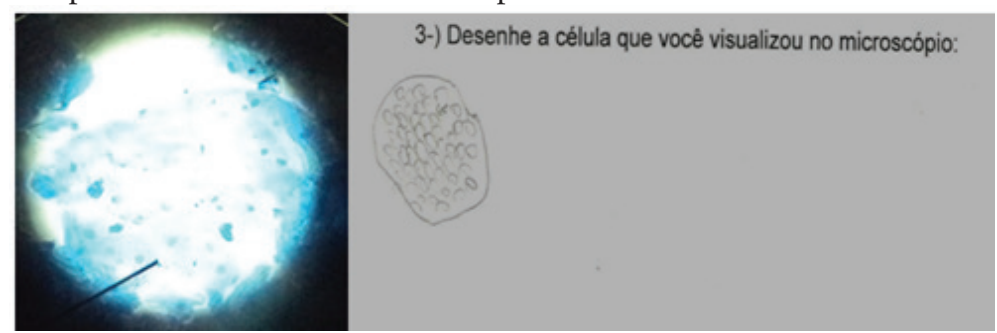

Figura 6: Lâmina do esfregaço bucal e desenho referente à lâmina do aluno A.

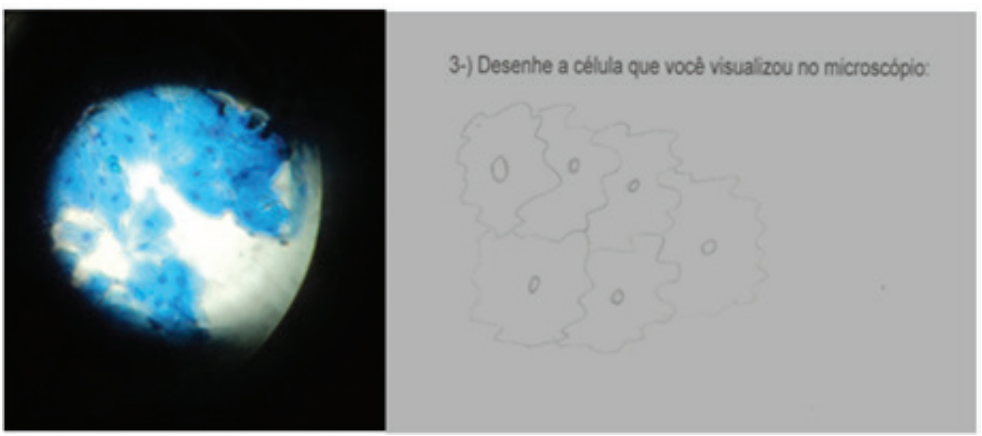

Figura 7: Lâmina do esfregaço bucal e desenho referente à lâmina do aluno B.

Ponderamos que para esta aula houve a necessidade do auxílio de um livro didático, a fim de comparar as células microscópicas projetadas na televisão com o material, para que pudessem perceber a diferença de tamanho em escala. Diante dos dados coletados, Alves (2011) apontou que a utilização de um microscópio com o auxílio de um livro didático pode realçar o aprendizado do conteúdo abordado "célula", aproximando os conteúdos teóricos da disciplina para a praticidade. Sendo assim, sugerimos que houve um aumento dos estímulos visuais decorrentes da utilização 
destes recursos. Percebemos, também, que houve a contextualização, para acomodar os esquemas didáticos evidenciados nos materiais quando os alunos surdos visualizaram suas próprias células. Este resultado foi muito satisfatório.

Nesta última aula adicional, foi proposta uma atividade para os alunos surdos em que pudessem confeccionar um modelo didático referente aos conteúdos aplicados no período da pesquisa, contando com a participação de dois alunos surdos.

Sendo assim, não foi aplicado questionário para avaliação, porém, foi possível analisar os modelos confeccionados pelos alunos e indicados nas figuras 8 e 9 abaixo:

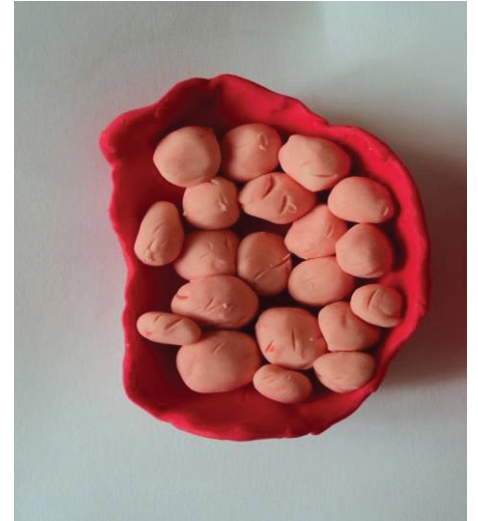

Figura 8: modelo confeccionado pelo aluno A.

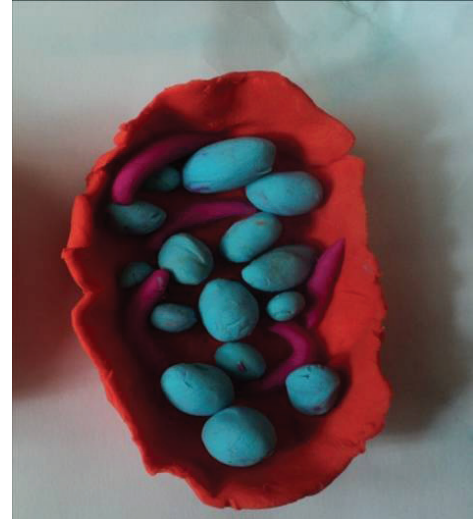

Figura 9: modelo confeccionado pelo aluno B.

Analisando os modelos didáticos elaborados pelos alunos, percebemos que a massa de modelar pode ser uma ferramenta para estimular os alunos surdos a desenvolverem a criatividade. Sendo assim, segundo Monteiro (2009), a estratégia de utilizar materiais simples para confeccionar modelos didáticos relacionados aos conteúdos das aulas proporciona a compreensão dos alunos surdos, já que além de criar, fortalece o aprendizado.

É interessante notar que a compreensão dos alunos surdos sobre os conteúdos de citologia e histologia ocorreu especificamente nas últimas aulas ministradas, conforme percebemos com a confecção dos modelos. Nesta perspectiva, evidenciamos que para a condução satisfatória destes conteúdos de Ciências e Biologia e partindo de uma perspectiva bilíngüe-bicultural (inclusão), é preciso contar com alguns elementos:

[...] 1) a necessidade, aceitação e o trabalho em conjunto com o intérprete da língua de sinais; 2) o desenvolvimento de pesquisas que busquem refletir sobre as questôes do léxico especifico às áreas de ensino; e 3) a busca, dos professores, de metodologias e as estratégias á realidade psicocognitivo-linguisticos dos surdos. (LACER-

DA; SANTOS, 2013 p. 223). 


\section{Conclusão}

Neste trabalho foi considerada positiva a utilização de recursos didáticos diferenciados, os quais foram aplicados nos conteúdos de citologia e histologia para o ensino dos alunos surdos. Desta forma, ao propor uma aula de forma contextualizada, o aluno surdo pode vivenciar uma experiência visual e sensorial, para desenvolver e estimular sua criatividade e o interesse por tais assuntos.

Ao proporcionar uma aula envolvendo teoria e prática, as chances são maiores de se obter a compreensão dos conceitos de Ciências e Biologia. Porém, vale ressaltar nesse estudo, que é indispensável a presença de um intérprete de LIBRAS em sala de aula, sinais específicos e estratégias diferenciadas.

Sendo assim, ao sincronizar a presença de um intérprete de LIBRAS e um professor titular, os quais podem fazer uso de diferentes recursos didáticos em sala de aula, a aprendizagem do aluno surdo poderá ter maior alcance, favorecendo nestes aspectos, o sucesso à inclusão escolar.

No contexto da inclusão, é de extrema importância a capacitação de profissionais da área. Além disso, é relevante a motivação de professores em elaborar aulas com metodologias inovadoras, que fujam do tradicionalismo, a fim de promover os conhecimentos científicos, beneficiando não apenas aos alunos surdos, bem como aos alunos ouvintes.

Assim sendo, no presente estudo percebemos que os recursos didáticos de maior impacto foram aqueles que promoveram os estímulos sensoriais e visuais.

\section{Referências}

ALVES, K. G.; I Simpósio Mineiro de Educação Química. O Ensino de Química para os surdos: a relevância dos aspectos visuais. 2011. (Simpósio).

AMARAL, S. F.; et. al. Utilização da lousa digital interativa em práticas pedagógicas para a educaçáo dos surdos. Unicamp, 2007.

CAMPOS, J. A. P. P.; DUARTE, M. O aluno com deficiência na EJA: reflexóes sobre o atendimento educacional especializado a partir do relato de uma professora. Revista Educaçáo Especial, Santa Maria, v. 24, n. 40, p. 271-284, maio/ago. 2011

COSTA, S. S. C.; KELMAN, C. A. Representaçóes sociais dos surdos do curso de graduação em Letras-Libras. Revista Educaçáo Especial. Santa Maria, v. 26 n. 46 p. 437-450. maio/ago. 2013.

CYSNEIROS-FILHO, A. A. A.; LEÃO, M. B. C. Recursos Educacionais tecnológicos para o ensino de química a surdos. Pernambuco, 2009. Disponível em <http://www.eventosufrpe.com.br/jepex2009/cd/resumos/ R1431-1.pdf>. Acesso em: 23 out. 2013.

DORZIAT, A.; ARAÚJO, J. R. O intérprete de língua de sinais no contexto da educação. Revista Brasileira de Educaçáo Especial, Marília, v. 18, n. 3, p. 391-410, jul/set. 2012.

DUBOC, M. J. O. A formaçáo do professor e a inclusão educativa: uma reflexão centrada no aluno surdo. Revista Centro da Educação. Cadernos: edição: 2005, n. 26 p. 4.

FERNANDES, S. Educação de surdos. 2. ed. Curitiba: Ibpex, 2011.

LACERDA, C. B. F.; SANTOS, L. F. Tenho um aluno surdo, e agora? Introdução à libras e educação de surdos. 1. ed. São Carlos: EDUFSCar, 2013. v. 1. 254p.

LINHARES, I. TASCHETTO, O. M. A citologia no ensino fundamental. Cascavel, 2009. Disponível em: <http://www.diaadiaeducacao.pr.gov.br/portals/pde/arquivos/1899-8.pdf >. Acesso em: 26 mar. 2013. 
Luiz Renato Martins Rocha - Alexandra Renata Moretti - Priscila Caroza Frasson Costa -

Fabiano Gonçalves Costa

MILAN, L. F. Maquetes táteis: infográficos tridimensionais para a orientação espacial de deficientes visuais. Rev. Parc Fec Unicamp. v. 1, 2008.

MONTEIRO, J. H. S. O ensino de biologia e química para alunos surdos no ensino médio da rede pública da cidade de Fortaleza: Estudo de caso, 2011. Dissertação (mestrado) - Universidade Federal do Ceará, Fortaleza.

MONTEIRO, R. Acessibilidade e inclusão digital: práticas de e-learning nas universidades públicas portuguesas. 2009. Disponível em: <http://repositorium.sdum.uminho.pt/handle/1822/10200 >. Acesso em: 20 out. 2013.

OLIVEIRA, J. S. A comunidade surda: perfil, barreiras e caminhos promissores no processo de ensino-aprendizagem em matemática. 78 p. Dissertação (Mestrado em Ensino de Ciências e Matemática) - Departamento de Pesquisa e Pós-Graduação, Centro Federal de Educação Tecnológica, Rio de Janeiro, 2005.

PEIXOTO, R. C. Algumas consideraçōes sobre a interface entre a Língua Brasileira de Sinais (LIBRAS) e a Língua Portuguesa na construção inicial da escrita pela criança surda. Cad. Cedes, Campinas, v. 26, n. 69, p. 205-229, maio/ago. 2006.

PRESIDÊNCIA DA REPÚBLICA, Casa Civil. Decreto 10.436, de 24 de abril de 2002. Disponível <http:// www.planalto.gov.br/ccivil_03/_ato2004-2006/2005/decreto/d5626.htm> Acesso em: 27 out. 2013.

SASSERON, L. H.; CARVALHO, A. M. P. Alfabetização Científica: Uma revisão bibliográfica. Investigaçóes em Ensino de Ciências, v. 16, p. 59-77, 2011.

SPENASSATO, D.; X Encontro gaúcho de educação matemática. Inclusão de alunos surdos no ensino regular: investigação das propostas didático-metodológicas desenvolvidas por professores de matemática no ensino médio da EENAV, 2009.

SKLIAR, C. (Org.). A surdez: um olhar sobre as diferenças. Porto Alegre: Editora Mediação.1998.

VYGOTSKI, L. S. Fundamentos da defectologia. Madri: Visor, 1997. Obras escogidas, 5.

\section{Nota}

${ }^{1}$ A Universidade Estadual do Norte do Paraná - UENP está divida em três campus (três cidades diferentes), o presente estudo foi realizado no campus Luiz Meneghel - CLM, situado na cidade de Bandeirantes/Paraná, através do Centro de Ciências Biológicas - CCB.

\section{Apêndices}

\section{Questionário aula 1 (prévio e pós)}

1) O que é citologia?
a) Estudo dos animais
b) Estudo das células
c) Estudo dos alimentos

2) $\mathrm{O}$ que são células?
a) Constitui os organismos vivos
b) Sâo animais que vivem apenas na Terra
c) São animais que vivem apenas na água

Questionário aula 2 (prévio e pós)

1) São seres procariontes

a) Cachorro 

b) Gato
c) Bactéria
d) Cadeira

2) São seres eucariontes
a) Animais e plantas
b) Gaveta
c) Pedra
d) Bactéria

3) Nas células eucariontes
a) O céu é azul
b) O mar é vermelho
c) Tem um núcleo organizado
d) Não possui núcleo

\section{Questionário aula 3 (prévio e pós)}

1) Nome dado ao espaço intra-celular das CÉLULAS:

a) Núcleo

b) DNA

c) Membrana Plasmática

d) Citoplasma

2) Camada que envolve a CÉLULA externamente:
a) Membrana Plasmática
b) Citoplasma
c) Núcleo
d) DNA

\section{Questionário aula 4 (prévio e pós)}

1) Célula que compóe o sangue
a) Glóbulos vermelhos
b) Neurônio
c) Fio de cabelo
d) Estômago

2) Desenhe um tipo de célula que você aprendeu na aula.

\section{Questionário aula 5 (prévio e pós)}

1) Recurso que se utiliza para visualizar as células:

a) Bicicleta 
Luiz Renato Martins Rocha - Alexandra Renata Moretti - Priscila Caroza Frasson Costa Fabiano Gonçalves Costa
b) Microscópio
c) Padaria
d) Banco

2) Exemplo de tecido epitelial:
a) Sangue
b) Ossos
c) Revestimento da boca
d) Cartilagem

3) Desenhe a célula que você visualizou no microscópio:

\section{Correspondência}

Luiz Renato Martins da Rocha - Universidade Tecnológica Federal do Paraná, Campus Cornélio Procópio. Avenida Alberto Carazzai, 1640, Centro, CEP: 86400-000 - Cornélio Procópio, Paraná - Brasil.

E-mail: renatotils@uenp.edu.br - alexandra.moretti@hotmail.com - priscilacarozza@uenp.edu.br - fabianocosta@uenp.edu.br

Recebido em 21 de julho de 2014

Aprovado em 16 de fevereiro de 2015 